\title{
Qualitative Analysis of the Management of Three Public Universities in the State of Minas Gerais-Brazil
}

\author{
Franciele M. C. FERREIRA ${ }^{1}$ and Henor Arthur SOUZA ${ }^{2}$ \\ 1. Federal Institute of Education, Science and Technology of Minas Gerais - Congonhas Campus - Avenue Michael Pereira de \\ Souza, 3007 - Campinho - Congonhas - Minas Gerais - CEP: 36415-000 \\ 2. Federal University of Ouro Preto (UFOP) - University Campus, s/n, Morro do Cruzeiro, CEP 35400-000,Ouro Preto - MG,
}

\begin{abstract}
Many Brazilian federal universities do not make use of a concrete and effective maintenance policy of its public buildings. Taking this fact into consideration, the objective of this work is to contribute with an assessment of the current maintenance management carried out in three federal universities in the State of Minas Gerais: the UFOP (Federal University of Ouro Preto), UNIFEI (University of Itajubá) and the UFMG (Federal University of Minas Gerais). These universities were chosen because they have buildings with metal structures and also for being a reference in the state of Minas Gerais, which is the largest steel producer in Brazil. Knowledge was sought about the management of the campus infrastructure maintenance by raising questions about the main tools used by managers and other professionals in the field. The adopted methodology was qualitative and performed through semi-structured interviews conducted via email, with servers working directly or indirectly within each building maintenance system. The results show lacking a well-formulated plan and building maintenance programs as well as a specialized and qualified skilled labor force for the performance of services.
\end{abstract}

Key words: Building maintenance, management, public buildings, life cycle.

\section{Introduction}

It is true to say that some maintenance activities could be prevented if everyone involved in the construction process were committed to the quality of the final product. Nevertheless, there is not a single building that is free from the depreciation process and the natural wear and tear of the materials used to build it. Some maintenance activities are inevitable and should be oriented towards delivery of the completed building completed and should have an accompanying technical support system for the maintenance and upkeep of the structure in question [1].

Maintenance is defined by the Rule NBR 14037 [2], as the set of activities to be undertaken to preserve or restore the functional capacity of the building and its constituent parts in order to meet the needs and safety

Corresponding author: Name, degree, academic title if any, research fields: of its users.

The planning of maintenance services requires the preparation of a detailed forecast of working methods, tools and equipment, special conditional access, development schedule and duration of maintenance services according to the recommendations of NBR 5674 [3].

Failures of maintenance affect the technical, operational and administrative aspects; however, the greatest problem is the lack or inadequacy of the building's maintenance plan.

According to Moraes [4], in the planning process, the maintenance priorities are determined, thus evaluating existing conflicts between minimizing costs, maximizing building performance while minimizing the risk of failure. At this stage, information is generated to create the maintenance plan, which is key to programming and recording future activities.

With all information identified and the necessary 
documentation implemented, the maintenance plan must then be computerized for the control of the entire team. The programming is generated with the schedule and recording of activities for a certain period of time.

According to Silva [5], one only manages what one knows. The lack of a database makes the manager follow any path, which is not always effective, especially in times of economic crisis, where financial resources are increasingly scarce. Technical reports should be made available to all involved in the project and, vitally, at times of decision making.

The management evaluation strategy of building maintenance must follow the following steps: inspection; identification of the type of maintenance strategy; verification of the coherence of the identified strategy with the expectations of its users; execution of building inspection for verification of non-compliance techniques of use and maintenance; documentation analysis for the building to complement data provided by the inspection and elimination of errors in maintenance contracts with subcontractors; assessment of the maintenance team and their training; design and ability to meet certain actions; evaluation of the maintenance costs; and, finally, appraising the quality of the service provided [6].

According to Carlino [7], when trying to understand the difficulties of public administration, it is necessary to reflect on some issues such as: (a) How to treat the maintenance of public buildings so that they can be preserved and not depreciate over time? (b) How to develop a focused building maintenance plan for continuous improvement and shift of paradigms that satisfactorily meets employees' demands in their daily activities and others who enjoy the services provided in these buildings? (c) How can the quality of service and preservation of public property with features not always available be maintained when the number of staff is constantly decreasing?

In Malaysia between 2006 and 2009, it was reported by Lateef et al. [8] that more than 14 billion
USD were allocated for the construction and maintenance of its public universities.

Maintenance costs are a significant part of the operating cost. For example, the amount spent on maintenance budget in Europe is around 1,500 million euros per year [9]. Today, it is accepted that maintenance is a key function to sustain the long-term profitability of organizations.

The maintenance of new buildings, renovation and modernization of older constructions require considerable experience and commitment of human and material resources. This is because the changes in climatic conditions and a lack of maintenance culture are responsible for aging and deterioration of buildings and educational equipment [10]. However, most managers and educational managers who constantly use the educational facilities do not have the maintenance planning knowledge of these facilities.

Sangjun and Yukio [11] showed that studies on the management and maintenance of facilities have increased in Japan, but that there is still a lack of government initiatives for the maintenance of public facilities.

Estermann and Pruvot [12] stated that financial sustainability will be a major challenge for universities in the next decade: only those institutions that have a solid and stable financial structure in their income stream will be able to fulfill their mission in responding to the current challenges in an increasingly complex and global environment.

\section{Methodology}

When it comes to mining, the first reference is well defined in the state of Minas Gerais. It is in this state where there are the most concentrated steel factories and the higher production of steel in Brazil. Due to this high-concentration area, three federal universities were chosen because of their great importance in the mining industry: the UFOP (Federal University of Ouro Preto), UNIFEI (University of Itajubá) and the UFMG (Federal University of Minas Gerais), the 
largest in the state. All these universities have buildings with different building typologies, among them buildings with metal structures. This object points to a methodological approach to qualitative research. During the case studies, two basic sources of information were used: semi-structured interviews and documentary analysis (GODOY, 1995; LAVILLE and DIONE, 1999) [13, 14]. The interviews were conducted via email with the officials responsible for the infrastructure maintenance sector of the universities studied from August 2015 to April 2016.

\section{Results}

\subsection{UFOP}

The UFOP was established on August 21, 1969 from the merger of two century-old institutions of higher education: the School of Pharmacy founded in 1839 and the School of Mines founded in 1876, both located in Ouro Preto, Minas Gerais.

Among the buildings that are part of the UFOP, those with the different typologies cited are the School of Pharmacy and the School of Mines (Figs. 1 and 2).

Currently UFOP has a maintenance department, located next to the campus town hall, which is responsible for receiving requests and delegating services containing a specific order of priority. Usually, the department head makes the requests of different needs such as spare bulbs, the installation of partitions, room painting, closing walls and so on. They refer to the maintenance department that scrutinizes the availability of staff to deliver the services and the material needed in the warehouse.

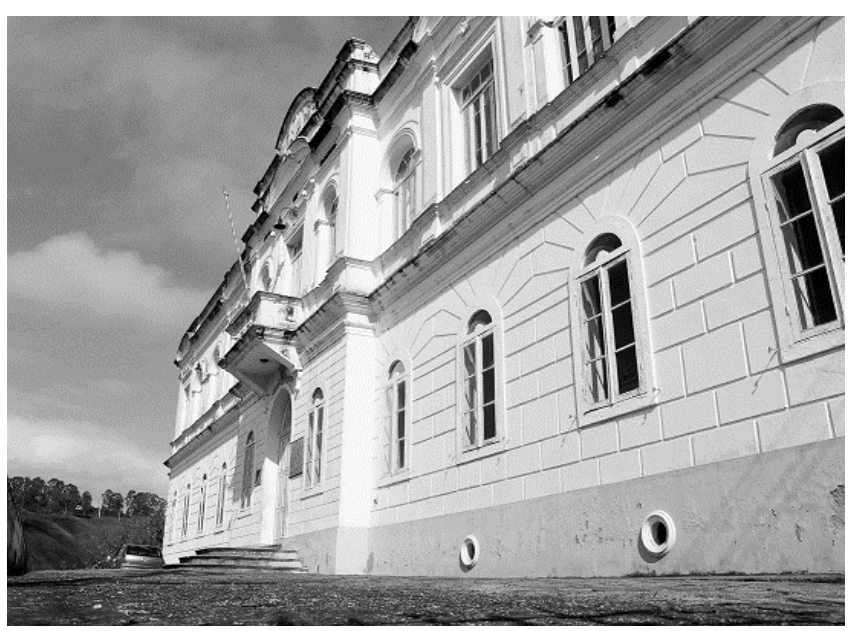

Fig. 1 Pharmacy School.

Source: Íris Jesus—Collection UFOP, 2015 [15].

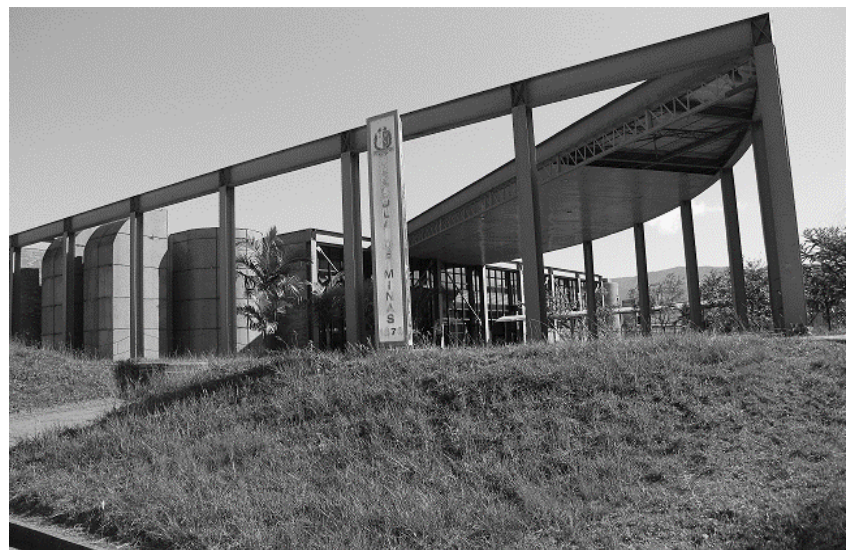

Fig. 2 School of Mines.

Source: Îris Jesus—Collection UFOP, 2015 [16]. 
As stated by the officials interviewed, the university does not have any preventative maintenance services, but only corrective maintenance when the services are repaired as a consequence of an existent issue.

Therefore, there is no policy and no prior planning of the activities that has taken place over the years; it is known that a light bulb will reach the end of its life expectancy, but it is uncertain to define when, how or even which parameters to establish if there is also a problem in the electrical network.

The UFOP maintenance services include the buildings of the campus itself, Morro do Cruzeiro, the buildings of the city center of Ouro Preto (i.e. the School of Mines, the Pharmacy School, the Cine Vila Rica Theater, the Convention Center, all the Federal University Residence Halls and the IFAC-Institute of Philosophy of Arts and Culture) in addition to the University Campus in the cities of Mariana (ICHS and ICS) and in João Monlevade.

According to the staff of the maintenance department, inventory control is performed through spreadsheets and then published on the university website. In reality, there is no control of the service demand. It is clearly uncertain to specify which buildings request an upgrade or repair service or if any of the buildings has placed more repair services than others, or if the requests are repetitive or from the same period.

The maintenance applied to the UFOP buildings has basically an emergency character, correcting repairs presented in the final degree of an emergency, earning the title of "very urgent". Even though some buildings present visible issues, the school managers do not raise these issues, because there is no systematization program for the needs and building maintenance; therefore, the issues are not eliminated.

\subsection{UNIFEI}

On November 23rd, 1913, the UNIFEI was founded under the personal initiative of lawyer Theodomiro Carneiro Santiago with the original name of IEMI
(Electro-technical Institute \& Itajubá Mechanics). It was the tenth School of Engineering founded in Brazil at the time. The federal government officially recognized the Institute on January 5, 1917.

The Laboratory Building with its conventional masonry and the metal-structured building, both located in the Campus of Itabira, are among the buildings of the Federal University of Itajubá with different building typologies (Figs. 3 and 4).

The Maintenance Building Division is subject to the Town Hall of Itajubá and the UNIFEI Dean of Administration. The Division currently has a staff of skilled employees and specialized contractors in their areas of competence who carry out maintenance activities on the campus.

How the UNIFEI corrective maintenance is applied is also noteworthy. Such maintenance occurs using the virtual platform “Ocomon”, i.e. occurrences monitor and computer equipment inventory. When a server detects a problem, the server logs onto the platform, selects the sector responsible for the problem area, types the issue area (e.g. constructive pathology, change furniture, etc.) and then "opens" a call for maintenance, describing concisely what was observed along with any criticisms and suggestions.

The outsourced services are surveillance, cleaning of the buildings, catering, and the provision of various other services. Among the services offered by the university maintenance are painting and electrical and minor repairs.

The university staff is composed of professional maintenance employees hired directly by the school, yet the majority of the staff are contracted public employees. Sporadically, when a specific service is needed and the university employees do not have requisite knowledge, outsourced staff are hired to fulfill the stipulated demand.

Currently, the university has not yet presented a plan or maintenance program. The specific building maintenance strategies for buildings with metallic structures are under the responsibility of a particular 


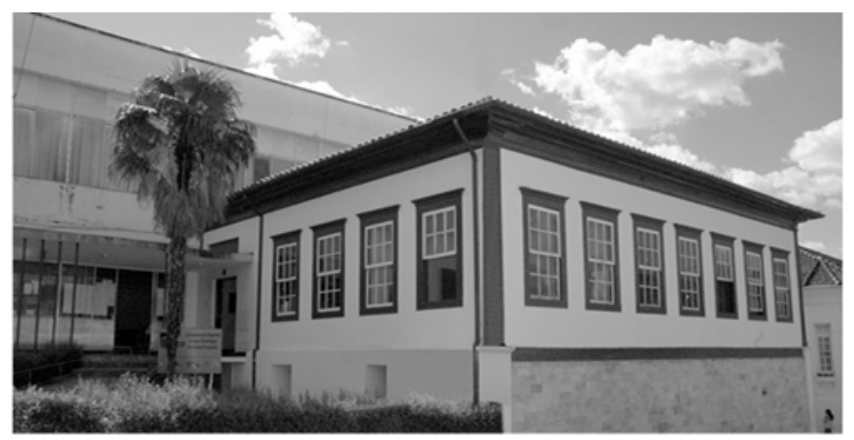

Fig. 3 Laboratory.

Source: Office Communication, UNIFEI, 2015 [17].

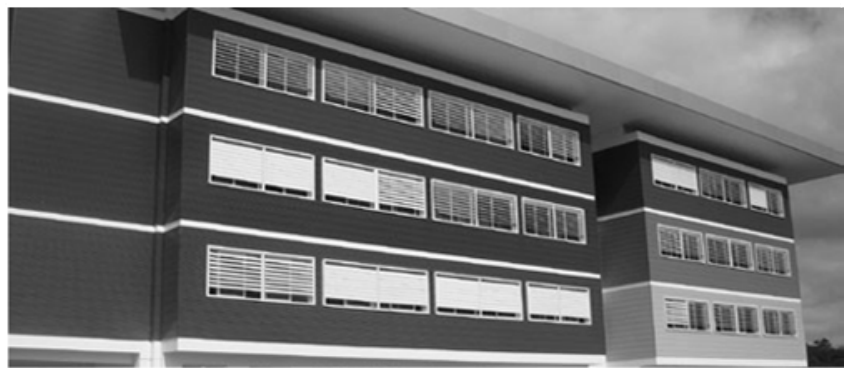

Fig. 4 Metal structures building, Itabira.

Source: Office Communication, UNIFEI, 2015 [17].

outsourced company. Periodically, there has been some kind of mapping to analyze the states, conditions and conservation of these buildings.

\subsection{UFMG}

The UFMG is the largest in the state of Minas Gerais and is one of the top five federal universities in Brazil. Like most universities, its origin is comprised of a fusion of several individual colleges dating back to the Brazilian colonial period.

In 1907, the University of Dentistry was created; four years later, the Schools of Medicine and Engineering were established along with the School of Pharmacy, now annexed to the Dentistry School. The Mechanics Institute (now called The "Technical College") and the Rectory were the first buildings erected in what is now the Pampulha Campus.

The campus was only effectively occupied by the university community in the 1960s with the construction of the buildings that house most academic units today. The buildings that are part of the main campus of UFMG with different building typologies include the ICEB (Institute of Sciences and Biology) and the building of the Service Square (Figs. 5 and 6).

The SIM (superintendent of infrastructure and maintenance) was established in January 2011, encompassing the Department of Construction, the Department of Maintenance and the purchasing and budget consulting. In October 2012, the newly created Department of Projects (DP-SIM) was incorporated into the SIM structure, responsible for Executive Projects Works of Reform and Small Service Projects, while purchases became the responsibility of the PRA (pro-rectory administration). The SIM performed approximately 50,000 maintenance operations in 2013 and has currently in its portfolio 350 projects.

Monthly reports are produced reflecting each kind of service (viz. building, hydraulic, electrical and equipment) performed on every unit in each of the UFMG campuses (i.e. Pampulha, Health, HC, ICA, Diamantina, Pedro Leopoldo Farms and Igarapé).

With the same objectives as those specified above, the Reform Monitoring System was created in order to fulfill reforms and small services. Using the Institutional 
Fig. 5 ICEB.

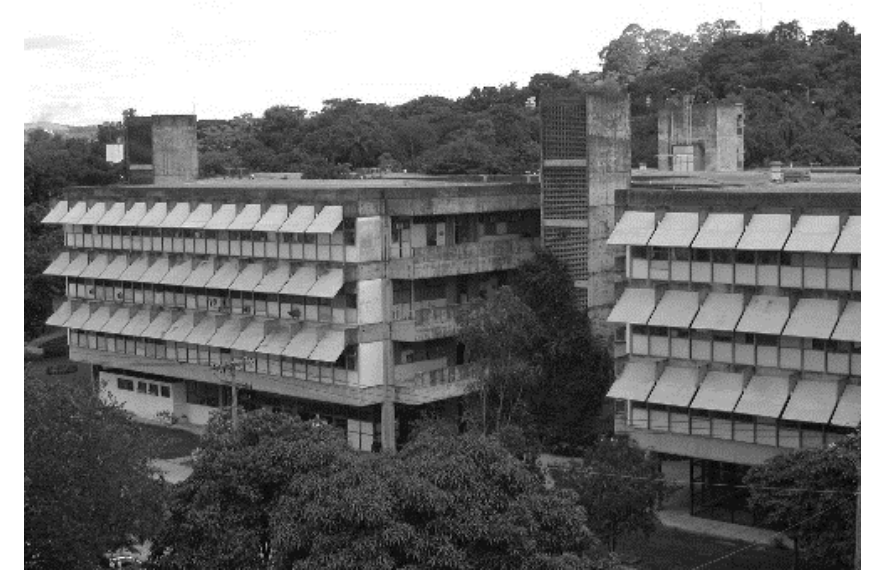

Source: Foca Lisboa/UFMG, 2015 [18].

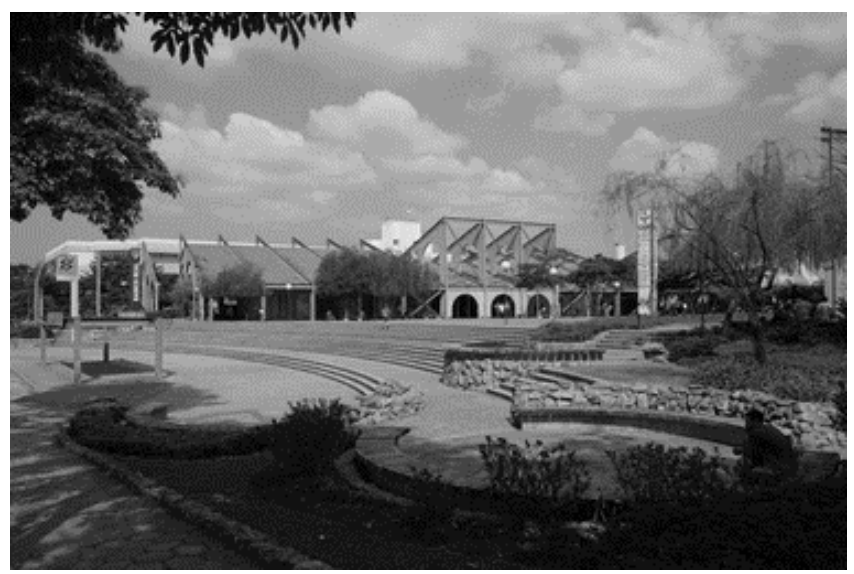

Fig. 6 Service square building.

Source: Foca Lisboa/UFMG, 2015 [18].

Development Project, all the filing sector material, approximately 50,000 documents, were scanned.

Moreover, a survey of the situation of all the buildings of the Campus Pampulha was performed. The results of this work were collected into a digital file with multiple entries, recorded on a CD-Rom containing the main pathologies, special equipment and as built of the buildings and green areas.

Outsourced services are only those that depend on specialized and skilled labor. More than half of the professionals involved in the maintenance service are outsourced. The systems of information or software used by UFMG for maintenance management are generated through general networks and spreadsheets.

\section{Discussion}

From the actions presented in Table 1, it is possible to compare the main maintenance management actions currently used by the three federal universities cited.

This comparison was carried out through the responses of interviews with those professionals involved in the maintenance of the buildings of the Federal Universities. The UFMG, perhaps because it is the largest university of the state and since it has the greatest budget volume, presents the most detailed maintenance management system with a survey of the conservation status of all its buildings, although it may already be out of date, but nevertheless containing an important amount of data and information capable of 
Table 1 University management maintenance actions (continue).

\begin{tabular}{|c|c|c|c|}
\hline Maintenance actions & UFOP & UNIFEI & UFMG \\
\hline $\begin{array}{l}\text { Plan or maintenance } \\
\text { program }\end{array}$ & Not available & Not available & Not available \\
\hline $\begin{array}{l}\text { Professionals involved } \\
\text { in maintaining }\end{array}$ & $\begin{array}{l}\text { Large part of the } \\
\text { professional framework } \\
\text { of maintenance is now } \\
\text { outsourced. }\end{array}$ & \begin{tabular}{|l|} 
The professional staff of \\
maintenance is composed of \\
employees of the university and, \\
mostly, by public employees. \\
\end{tabular} & $\begin{array}{l}\text { In Demai there are currently } 50 \text { workers who are } \\
\text { permanent staff and } 150 \text { outsourced employees. }\end{array}$ \\
\hline \multirow[t]{3}{*}{$\begin{array}{l}\text { Outsourced } \\
\text { maintenance services }\end{array}$} & $\begin{array}{l}\text { Only very specific } \\
\text { services are external to } \\
\text { the University’s staff. }\end{array}$ & $\begin{array}{l}\text { Outsourced services are } \\
\text { surveillance, building cleaning, } \\
\text { restaurants and various other } \\
\text { services. }\end{array}$ & $\begin{array}{l}\text { Maintenance/conservation lifts; } \\
\text { Maintenance/conservation of energy generators; } \\
\text { preventive/corrective maintenance of energy } \\
\text { substation; preventive/corrective maintenance of } \\
\text { fire hydrants; Maintenance/fire extinguishers } \\
\text { recharge; Service. }\end{array}$ \\
\hline & & & $\begin{array}{l}\text { Painting/revitalization with supply of materials; } \\
\text { Delivery services/tempered glass installation; } \\
\text { plaster lining; PVC liner; drywall walls; vinyl } \\
\text { flooring; Paviflex floor; stones, etc. }\end{array}$ \\
\hline & & $\begin{array}{l}\text { Cleaning, restaurants and } \\
\text { various other services }\end{array}$ & $\begin{array}{l}\text { Maintenance/fire extinguishers recharge; Service } \\
\text { Painting/revitalization with supply of materials; } \\
\text { Delivery services/tempered glass installation; } \\
\text { plaster lining; PVC liner; drywall walls; vinyl } \\
\text { flooring; Paviflex floor; stones, etc. }\end{array}$ \\
\hline $\begin{array}{l}\text { Information systems } \\
\text { used to manage }\end{array}$ & $\begin{array}{l}\text { Electronic service } \\
\text { request system and } \\
\text { Excel spreadsheet }\end{array}$ & $\begin{array}{l}\text { Virtual platform } \\
\text { “Ocomon”-occurrences } \\
\text { monitor and computer } \\
\text { equipment inventory }\end{array}$ & $\begin{array}{l}\text { For the O.S system (Service Orders): The system } \\
\text { works via the UFMG network to request } \\
\text { maintenance services. Excel worksheet is used for } \\
\text { recording reform requests. }\end{array}$ \\
\hline $\begin{array}{l}\text { Building } \\
\text { inspection-survey of } \\
\text { the conservation status } \\
\text { of buildings }\end{array}$ & $\begin{array}{l}\text { Only in the Mining } \\
\text { School building has a } \\
\text { survey of the } \\
\text { conservation status been } \\
\text { carried out. }\end{array}$ & $\begin{array}{l}\text { Eventually there is a gross } \\
\text { evaluation of conditions, visual } \\
\text { observation and cleaning } \\
\text { operation. }\end{array}$ & $\begin{array}{l}\text { In 2007, Demai created a PDI-Institutional } \\
\text { Development Plan, whose objective was to make } \\
\text { the survey of conditions and conservation status } \\
\text { of all the buildings of the campus of UFMG. The } \\
\text { project was completed in } 2011 \text {. }\end{array}$ \\
\hline $\begin{array}{l}\text { Buildings with steel } \\
\text { structure }\end{array}$ & $\begin{array}{l}\text { Building of the School } \\
\text { of Minas and the } \\
\text { Medical School }\end{array}$ & $\begin{array}{l}\text { Building } 2 \text { and Building José de } \\
\text { Alencar }\end{array}$ & $\begin{array}{l}\text { The Knowledge Center of the building is a } \\
\text { metallic structure and glass façade. The façade of } \\
\text { the administrative building of the Law School has } \\
\text { a metal frame. The rectory building façade has a } \\
\text { metal frame. The Complex Service Square is a } \\
\text { metallic structure. }\end{array}$ \\
\hline $\begin{array}{l}\text { Specific maintenance } \\
\text { actions for the } \\
\text { buildings with metal } \\
\text { structure } \\
\end{array}$ & $\begin{array}{l}\text { There are no budgetary } \\
\text { questions. }\end{array}$ & \begin{tabular}{|l|} 
Specific strategies with \\
reference to the steel structures \\
are in charge of a company from \\
Itabira town.
\end{tabular} & $\begin{array}{l}\text { There is no maintenance strategy for these } \\
\text { buildings. The locksmiths and painters perform } \\
\text { interventions periodically with the purpose of } \\
\text { repairing and conserving the structures. }\end{array}$ \\
\hline $\begin{array}{l}\text { Distribution of } \\
\text { maintenance between } \\
\text { the existing buildings }\end{array}$ & $\begin{array}{l}\text { The distribution follows } \\
\text { the order of the requests } \\
\text { sent, except for services } \\
\text { that need priority. }\end{array}$ & $\begin{array}{l}\text { The building maintenance staff } \\
\text { ranks occurrences in order of } \\
\text { need and importance, so it can } \\
\text { be said that the distribution is } \\
\text { centralized. }\end{array}$ & $\begin{array}{l}\text { Routine maintenance services are requested by } \\
\text { the General Services Sectors of the Units through } \\
\text { the O.S (Service Orders). Reform services are } \\
\text { requested by the directors of the Units to the } \\
\text { Management Provost through e-mails or letters. }\end{array}$ \\
\hline
\end{tabular}

generating more effective and targeted interventions. Also, the same institution has outsourced maintenance services to a greater degree, and has detailed the outsourced service framework contemplated to the greatest extent. The only institution that presents in its professional institution itself all the work with the building maintenance services is the UNIFEI.

\section{Conclusions}

Within the comparison between the three federal universities of Minas Gerais, it can be said that the main management tool, i.e. the creation of a building maintenance plan or program guiding the activities and distributing their actions within a specific period of time, is lacking in each institution. 
Another very significant issue that needs to be addressed is the lack of an effective database of the activities being carried out, together with a database of the current condition of the buildings.

The existing information system in universities today is limited only by the survey of demands or requests not being used as a management tool. The efficient management of maintenance and quality requires greater knowledge of the reality of the buildings and the actions or interventions that are performed.

In Brazil today, the outsourcing of the workforce is a reality and needs to be discussed further. In some interviews, professionals attributed the discontinuance of the services to the lack of commitment from the outsourced labor workers. Perhaps a more detailed survey of the outsourced teams would show whether this contention is a reality or not. Universities that have buildings with different construction typologies were chosen to determine which specific actions exist in the maintenance of each building. However, it is clear that there is no particular concern to share the role in actions for these typologies and buildings with metal structures, which often do not receive specific interventions. Perhaps this is not only a budgetary problem, but it also comes as a direct result of the lack of the aforementioned maintenance plan.

\section{Acknowledgments}

Thanks are given to FAPEMIG (Foundation for Research Support of the State of Minas Gerais) for the support given.

\section{References}

[1] Barbosa, P. B., and Pusch, J. 2011. "The Design Intent for Use of the Building: The Pursuit of Professional Excellence.” Program for Excellence in CREA-PR projects, Curitiba.

[2] Brazilian Association of Technical Standards. 2011. Guidelines for Preparation of User Manuals, Operation and Maintenance of Buildings - Requirements for Preparation and Presentation of Content. NBR 14,037.

[3] Brazilian Association of Technical Norms. 2012.
Building Maintenance-Requirements for Maintenance Management System. NBR 5,674.

[4] Moraes, L. de O. G. 2012. "Study of the Structure of Information in the Management Process of Maintaining Lidia Office Buildings.” Paper of Lidia Oliveira Guimaraes Moraes, São Paulo.

[5] Silva, A. S. 2014. "Business Plan: Management of the Building Maintenance in Banking Networks in Curitiba (PR). Specialization in Maintenance Management.” A paper of Federal Technological University of Paraná, Curitiba.

[6] Neto, P. G. A. 2015. "Building Maintenance in Public Buildings, a Study on the Legislation.” E\&S-Engineering and Science 1 (3): 85-93.

[7] Carlino, A. E. 2012. Improvements of the Maintenance Processes in Public Buildings. San Carlos: UFSCar.

[8] Lateef, O. A. A., Khamidi, M. F., and Idrus, A. 2012. "Appraisal of the Building Maintenance Management Practices of Malaysian universities.” Journal of Building Appraisal 6: 261-75.

[9] Parida, A., and Kumar, U. 2009. Maintenance Productivity and Performance Measurement. Handbook of Maintenance Management and Engineering.

[10] Lind, H., and Muyingo, H. 2012. "Building Maintenance Strategies: Planning under Uncertainty.” Property Management 30 (1): 14-28.

[11] Sangjun, Y., and Yukio K. 2010. "Investigation of the Maintenance Condition in Public Facilities Focus on Comparison of the Municipalities in Tokyo.” Journal of Asian Architecture and Building Engineering 9 (1): 125-30.

[12] Estermann, T., and Bennetot Pruvot, E. 2011. Financially Sustainable Universities. European Universities Diversifying Income Streams. Brussels: EUA Publications.

[13] Godoy, A. S. 1995. "Qualitative Research: Basic Types.” Journal of Business Administration 35 (3): 20-9.

[14] Laville, C., and Dionne, J. 1999. The Construction of Knowledge. Belo Horizonte: UFMG.

[15] Íris, J. 2016. UFOP Collection, Public Use. Accessed in June 2016. http://www.saci2.ufop.br/servico_fotos_ album?id=454.

[16] Íris, J. 2016. UFOP Collection, Public Use. Accessed in June 2016. http://www.saci2.ufop.br/servico_fotos_ album?id=455.

[17] Office Communication. 2015. UNIFEI. Accessed in November 2015. https://www.unifei.edu.br/galeria/ galerias-fotos.

[18] Foca, L. 2015. UFMG. Accessed in November 2015. https://www.ufmg.br/online/fotografia/arquivos/000194.s html. 